Scientific Journal of October 6 University

ISSN (Print): 2314-8640

ISSN (Electronic): 2356-8119

Published by October 6 University (C) All Rights Reserved

Available online at: http:// sjou.journals.ekb.eg

Original Article
Citation: Kadry MS and Hazem MS (2014). Biopharmacodynamical Effect of Clindamycin and Spectinomycin Combination in Experimentally E. Coli Infected Broilers. Sci.J. of Oct. 6 Univ.2(2), 166-174.

Copyright: (C) 2014 Kadry MS and Hazem MS. This is an open-access article distributed under the terms of the Creative Commons Attribution License, which permits unrestricted use, distribution, and reproduction in any medium, provided the original author and source are credited.

\title{
Biopharmacodynamical Effect of Clindamycin and Spectinomycin Combination in Experimentally E.Coli Infected Broilers
}

\author{
*Kadry Mohamed Sadek ${ }^{1}$ and Hazem Mohammed Shaheen ${ }^{2}$ \\ ${ }^{1}$ Department of Biochemistry, Faculty of Vet. Med., Damanhour University, Damanhour, Egypt. \\ ${ }^{2}$ Department of Pharmacology, Faculty of Vet. Med., Damanhour University, Damanhour, Egypt.
}

\section{Received: 17-03-2014/ Revised: 03-04-2014 / Accepted: 06-04-2014}

\begin{abstract}
Antimicrobials are co-administered frequently worldwide in medical as well as veterinary practices. Often, the therapeutic efficiency of two antimicrobial drugs may induce adverse effects. In this study, the possibility of a clindamycin/spectinomycin interaction effect and the efficacy of the combination were investigated in 23 dayold chickens experimentally infected with $E$. coli. The challenged chickens were orally treated with Clindamycin $(11 \mathrm{mg} / \mathrm{kg}$ body weight) or spectinomycin $(51.1 \mathrm{mg} / \mathrm{L})$ for 5 successive days with a combination of both drugs at therapeutic and half-therapeutic doses. Two blood samples were collected from five chickens of each group on the $4^{\text {th }}$ day during the treatment course and on the $2^{\text {nd }}, 7^{\text {th }}, 14^{\text {th }}$ and $21^{\text {st }}$ days post-treatment. The results revealed that co-administration of clindamycin/spectinomycin reduced the severity of clinical signs and altered the biochemical function parameters related to liver, kidney and of oxidative stress. The effect of both drugs was short-lived, and most of the parameters returned to normal within 2 weeks after administration of them. It is concluded that, the therapeutic doses co- administration of clindamycin/spectinomycin reduced the severity of $E$. coli infection clinical signs and showed significant alterations in some liver and kidney function parameters as well as oxidative stress. This effect is short-lived and most of the parameters went back to normal within 2 weeks post drug(s) administration.
\end{abstract}

Key Words: Biochemical, Clindamycin, Bpectinomycin, Broilers, Escherichia coli

\begin{abstract}
Introduction
Avian colibacillosis continues a problem in poultry production and remains one of the major serious endemic and economic threats affecting the poultry industry worldwide. It causes mortality and destruction of the flocks ${ }^{(1)}$. Avian pathogenic Escherichia coli (APEC) causes airsacculitis, polyserositis, septicaemia and diseases, primarily extraintestinal, in chickens, turkeys and other avian species. APEC is found in the intestinal microflora of healthy birds, and most of the diseases associated with these bacteria are secondary to environmental factors and predisposing factors in the hosts ${ }^{(2)}$.
\end{abstract}

The in vitro sensitivity of these pathogens to antibiotics, intervention to address these infections may be warranted. During and after therapeutic intervention, the flock should be carefully evaluated as to the success of treatment. These evaluations can be performed by attending veterinarian or by service personnel under the veterinarian's direction. Accurate records should be maintained on all treatment outcomes and included in the farm history records for future reference ${ }^{(3)}$. Regardless of the actual contribution that antibiotic use in animal production has on the incidence of antibiotic-resistant infections in humans, serious consideration is being given to establishing regulations that would severely restrict the use of antibiotics in animal production ${ }^{(1)}$. If antibiotic use is restricted in poultry production, it would be anticipated that colibacillosis would become an even greater problem. Therefore, there is a real need to find a new approach to antibiotic use for the prevention and treatment of colibacillosis in poultry production.

One of these approaches is the co-administration of different antimicrobials. This may, however, result in unpredictable therapeutic results, potentially reducing the therapeutic efficacy or increasing the toxicity of the administered drugs ${ }^{(4)}$.

There are some very efficacious antimicrobials, clindamycin and spectinomycin, are frequently 
used as prophylactic medications, as well as therapeutically ${ }^{(5)}$.

Clindamycin inhibits protein synthesis in susceptible bacteria by binding to the $50 \mathrm{~S}$ subunits of the bacterial ribosomes and preventing peptide bond formation. The lincosamides are usually considered bacteriostatic; however, when clindamycin is present at sufficient concentrations, it may be bactericidal towards sensitive organisms. It has a spectrum of activity that includes Mycoplasma species, Staphylococcus species, and Streptococcus species (except Streptococcus faecalis), as well as anaerobic organisms such as Clostridium perfringens. The administration of clindamycin to rats with peritonitis due to haemolytic E. coli reduce mortality. Subinhibitory concentrations of clindamycin can inhibit growth and haemolysin production by $E$. coli and reduce mortality in an animal model of haemolytic $E$. coli peritonitis. Oral absorption of clindamycin is high and unaffected by food. The drug is widely distributed into most tissues, including respiratory tissue, soft tissue, bones, and joints ${ }^{(6)}$.

Spectinomycin is active against a variety of aerobic gram-negative and gram-positive organisms as well as Mycoplasma species. Spectinomycin is clinically used primarily for its activity against gramnegative organisms, but some gram-positive organisms may also be susceptible to it. Spectinomycin binds to the 30 S ribosomal subunit of the microorganism and inhibits protein synthesis by preventing elongation of the polypeptide chain at the translocation step. It is slightly absorbed from the gastrointestinal tract. Twenty-four hours following oral administration, it is found at decreasing concentrations in kidney, liver, lung, muscle, and fat ${ }^{(7)}$.

Unfortunately, there is little published information concerning the use of clindamycin and spectinomycin to treat $E$. coli or other infections in poultry. These data are required to determine dosage schedules for clinical use in birds. Therefore, this study has been designed to investigate the efficacy of clindamycin and spectinomycin combination usage $E$. coli-infected chickens and the effects of this combination on some biochemical parameters indicative of the general health of the chickens.

\section{Material and Methods}

This study was carried out in strict accordance with the recommendations in the guide for the care and use of laboratory animals of the national Institutes of Health (NIH). The protocol was approved by the local committee on the ethics of animal experiments of the University of Damanhur. All efforts were made to minimize suffering of two hundred and fifty clinically healthy, unvaccinated one-day old unsexed Hubbard broiler chicks were used. The chickens were obtained from a commercial hatchery. They were placed in the animal housing at the Faculty of Veterinary Medicine, Damanhour University. The birds were monitored for two weeks for any apparent clinical signs of disease prior to drug administration. The temperature was maintained at $25 \pm 2{ }^{\circ} \mathrm{C}$, and humidity was maintained at $45-65 \%$. The chickens had free access to water and food without additives, such as antibiotics and growth promoters. Chemotherapeutic agents

Clindamed® (Clindamycin 40\%) was obtained from Arabcomed Co. Ltd. Egypt. Each 47 grams was equivalent to $40 \mathrm{gm}$. of the Cindamycin base. The recommended dose is $5-11 \mathrm{mg} / \mathrm{kg}$ body weight for five successive days in the drinking water $^{(8)}$.

Moraspectam® (Spectinomycin 50\%) obtained also from Arabcomed Co. Ltd. Egypt. Each 77 grams was equivalent to $50 \mathrm{gm}$. of the Spectinomycin base. The recommended dose is $51.1 \mathrm{mg} / \mathrm{L}$ for five successive days in the drinking water ${ }^{(5)}$.

E. coli challenge

E. coli strain O78 was obtained from the Animal Health Research Institute, Dokki, Giza, Egypt. The broiler chickens of the treated groups were orally infected at 23 days of age with a $1 \mathrm{ml}$ inoculum containing $10^{9} \mathrm{CFU}$ (colony forming units) as described by Chansiripornchai and Sasipreeyajan (9).

Efficacy of clindamycin and spectinomycin against E. coli

Prior to use in the birds, the sensitivity of the specific $E$. coli strain to clindamycin and spectinomycin was tested using the disc diffusion method. Clindamycin and spectinomycin discs (Oxoid, UK) were used. The diameters of the inhibition zones were interpreted by referring to the tables ${ }^{(10)}$.

\section{Experimental design}

On the $23^{\text {rd }}$ day of age, the chicks were classified into 10 groups of 25 chicks each as follows:

Group 1. These birds served as a control group (non-infected - non-treated).

Group 2. Non-infected birds were treated orally with clindamycin at a dose level of $11 \mathrm{mg} / \mathrm{kg}$ for 12 hours, once daily, for five successive days.

Group 3. Non-infected birds were treated orally with spectinomycin at a dose level of $51.1 \mathrm{mg} / \mathrm{L}$ for 12 hours, once daily, for five successive days.

Group 4. Non-infected birds were treated orally with a combination of clindamycin and spectinomycin at half-doses of each drug for 12 hours, once daily, for five successive days.

Group 5. Non-infected birds were treated orally with a combination of clindamycin and spectinomycin at the full doses for 12 hours, once daily, for five successive days.

Group 6. Birds were infected experimentally with E. coli.

Group 7. Infected birds were treated orally with clindamycin at a dose level of $11 \mathrm{mg} / \mathrm{kg}$ after the 
start of symptoms, available for 12 hours, once daily, for five successive days.

Group 8. Infected birds were treated orally with spectinomycin at a dose level of $51.1 \mathrm{mg} / \mathrm{L}$ after the start of symptoms, available for 12 hours, once daily, for five successive days.

Group 9. Infected birds were treated orally with a combination of clindamycin and spectinomycin at half doses, after the start of symptoms, available for 12 hours per each, once daily for five successive days.

Group 10. Infected birds were treated orally with a combination of clindamycin and spectinomycin at the full doses after the start of symptoms, available for 12 hours, once daily, for five successive days.

The clinical signs of $E$. coli infection in broilers were diarrhoea, lack of appetite and ruffled feathers. Before starting the treatment, three infected birds were slaughtered and examined postmortem for lesions and for bacterial isolation from liver and heart. At necropsy, the bird's liver, air sac and heart were aseptically excised, and swabs from liver and heart were incubated in beef infusion broth and then plated on MacConkey agar at $37^{\circ} \mathrm{C}$ for 24 hours. The serogroup of $E$. coli was confirmed by agglutination reaction with $E$. coli O78 antiserum.

\section{Sampling}

Blood samples were collected from the wing veins of chickens of all groups on the $4^{\text {th }}$ day of treatment and on the $2^{\text {nd }}, 7^{\text {th }}, 14^{\text {th }}$ and $21^{\text {st }}$ days post-treatment for biochemical studies. The sera were collected by centrifugation at $3000 \mathrm{rpm}$ for $15 \mathrm{~min}$. and kept frozen at $-20^{\circ} \mathrm{C}$ until used for biochemical analysis. Serum biochemical parameters were analysed by commercially available kit methods.

\section{Statistical analysis}

The recorded data were presented as the mean \pm SE. The significant differences were calculated based on two-way test of ANOVA, and $p<0.05$ was considered as significant between the groups. All statistical analyses were carried out using SigmaStat for Windows, version 2.0, Jandel Corp., San Rafael, CA, U.S.A.

\section{Results and Discussion}

The present study showed that non-infected chickens treated with clindamycin displayed significant increases in serum ALT and ALP activities on the $4^{\text {th }}$ day of treatment. Non-infected chickens treated with spectinomycin showed a significant increase in serum ALT activities on the $4^{\text {th }}$ day of treatment. Non-infected chickens treated with a half-dose of the clindamycin-spectinomycin combination revealed non-significant changes in serum ALT and ALP activities on the $4^{\text {th }}$ day of treatment and on the $2^{\text {nd }}$ day post-treatment. However, non-infected chickens treated with a full dose of the clindamycin-spectinomycin combination showed a significant increase in serum ALT on the $4^{\text {th }}$ day of treatment, Tables 1 and 2 . The previous investigations reported that many drugs induce changes in hepatic and renal functions $^{(11)}$. The increased ALT and ALP activities in the clindamycin and/or spectinomycintreated chickens might be attributed to alteration of membrane permeability or damage of the hepatic cells by direct effects of the drugs, resulting in escape of these enzymes to the plasma ${ }^{(12)}$. Our results parallel those obtained by Smith and Reynard $^{(13)}$, Plumb ${ }^{(14)}$ and Gilman ${ }^{(15)}$, who reported that both drugs at therapeutic doses caused minor elevations in these hepatic enzymes. Interestingly, chickens experimentally infected with $E$. coli but not treated with the antibiotics displayed nonsignificant changes in serum ALT on the $4^{\text {th }}$ day of treatment and on the $14^{\text {th }}$ and $21^{\text {st }}$ days post treatment. These results contrast with previous studies of Zaki, et al., ${ }^{(16)}$ who reported a significant increase in ALT in E. coli-infected chickens. The discrepancy might be due to differences in the ages of the chickens at infection or the dose and route of the $E$. coli infection.

Chickens experimentally infected with E. coli and treated with clindamycin showed no changes in serum ALT either on the $4^{\text {th }}$ day of treatment or the $2^{\text {nd }}, 14^{\text {th }}$ and $21^{\text {st }}$ days post-treatment. These results agree with Elmore, et al. ${ }^{(17)}$, who showed that clindamycin is associated with hepatotoxic activity and with abnormalities in liver enzymes. Clindamycin caused a significant increase in ALP in the E. coli-infected chickens on the $4^{\text {th }}$ day of treatment, and this is consistent with the results obtained by Plumb ${ }^{(14)}$. The chickens experimentally infected with $E$. coli and treated with spectinomycin showed no significant changes in serum ALT either on the $4^{\text {th }}$ day of treatment or the $2^{\text {nd }}$ and $14^{\text {th }}$ days post-treatment, which conflicts with the results of Smith and Reynard ${ }^{(13)}$, who reported that spectinomycin is associated with minor abnormalities in alkaline phosphatase, serum ALT and creatinine clearance. Regarding the effect of spectinomycin on ALP in chickens experimentally infected with $E$. coli, the results revealed non-significant changes in ALP on the $4^{\text {th }}$ day of treatment and on the $2^{\text {nd }}, 14^{\text {th }}$ and $21^{\text {st }}$ days post-treatment. These results do not agree with Plumb ${ }^{(14)}$, who found that spectinomycin increases ALP at single and multiple doses. The current study also included an evaluation of the effect of a combination of half-doses of clindamycin and spectinomycin. This treatment did not result in any significant changes in ALT activity on the $4^{\text {th }}$ day of treatment or on the $2^{\text {nd }}$ and $14^{\text {th }}$ days posttreatment. This result contrasts with the results of Ali (18), who found that the drug combination significantly decreased ALT in the experimentally infected chickens. The differences may be attributed to the age of the chick at infection and the dose of E. coli. The current study showed that 
non-infected chickens treated with clindamycin displayed a significant decrease in serum total proteins on the $2^{\text {nd }}, 7^{\text {th }}$ and $21^{\text {st }}$ days post-treatment, Table 3. In contrast, $\mathrm{Ali}^{(18)}$ and Mohamed ${ }^{(19)}$ found non-significant changes in the total serum protein of chickens treated with lincomycin and clindamycin. These differences may be attributed to the antibiotic doses, age of birds or the method of oral administration. Spectinomycin caused a significant decrease in total protein on the $7^{\text {th }}$ and $21^{\text {st }}$ days post-treatment in non-infected chickens. Non-infected chickens treated with the half and full doses of the clindamycin-spectinomycin combination displayed a significant decrease in total protein on the $2^{\text {nd }}$ day post-treatment. These results could reflect some pathological changes in the liver and kidney induced by these drugs. In contrast, Ali ${ }^{(18)}$ and Mohamed ${ }^{(19)}$ reported that the clindamycin-spectinomycin combination produced no changes in total protein in non-infected chickens. This discrepancy might be related to the antibiotic doses and method of oral administration. The chickens experimentally infected with $E$. coli but not treated with antibiotics exhibited a significant decrease in total protein on the $2^{\text {nd }}, 7^{\text {th }}$, $14^{\text {th }}$ and $21^{\text {st }}$ days post-treatment compared with the non-infected, non-treated chickens. The results obtained by El-Kadeem ${ }^{(20)}$ revealed a significant decrease in total protein in $E$. coli-infected chickens, thus supporting the results of the present study. These results could be due to pathological changes in the liver and kidney as a result of experimental infection with $E$. coli in chickens ${ }^{(21)}$. The amino acid utilisation as a defence against the pathogens and renal damage produced by bacteria could also explain the hypoproteinaemia observed in the infected chickens ${ }^{(22)}$. Experimentally infected chickens treated with the clindamycinspectinomycin combination at half or full doses showed significantly increased levels of total protein on the $14^{\text {th }}$ and $21^{\text {st }}$ or $7^{\text {th }}$ and $21^{\text {st }}$ days posttreatment, respectively. This shift toward the control values of total protein might be attributed to an improved liver status in the treated groups because the synthesis of albumin, the largest individual fraction in avian plasma, takes place in the liver. Alternatively, the treatment might inhibit renal excretion of albumin by improving the status of the kidneys. With respect to the effect of clindamycin and or spectinomycin on serum creatinine and uric acid, the present study revealed that the drugs induced a significant increase in creatinine level on the $2^{\text {nd }}$ day post-treatment. This effect of the drugs, alone or in combination, was observed in the non-infected chickens, Table 4 and 5. These results are consistent with those obtained by $\mathrm{Ali}^{(18)}$ and Mohamed ${ }^{(19)}$. The experimentally infected chickens that were not treated with the antibiotics demonstrated a significant increase in serum creatinine on the $2^{\text {nd }}$ day post-treatment compared with non-infected, non-treated chickens.
The previous results ${ }^{(18,20)}$ support these findings. Clindamycin administration in chickens experimentally infected with $E$. coli lead to a significant increase in creatinine on the $7^{\text {th }}$ day post-treatment. This result also agrees with the study by $\mathrm{Ali}^{(18)}$, who found that clindamycin significantly increased serum uric acid in infected chickens on the $1^{\text {st }}$ day post-treatment. On the other hand, spectinomycin caused non-significant changes in the creatinine levels in the infected birds ${ }^{(18)}$. The clindamycin-spectinomycin combinations at both half and full doses significantly increased creatinine on the $4^{\text {th }}$ day of treatment in the infected chickens. The study also evaluated the effect of experimental infection with $E$. coli on total antioxidant capacity (TAC) and lipid peroxidation (MDA, a biomarker of oxidative stress), Table 6 and 7 . The results revealed that there were significant decreases in TAC and significant increases in MDA compared with the non-infected group, and this reflects the increased oxidative stress induced by infection. MDA, an important product of lipid peroxidation, is produced as a result of the peroxidation of fatty acids containing three or more double bonds. The MDA product can crosslink membrane elements and affect the ion exchange across the cell membranes, which results in changes in ion permeability and enzyme activity. In this study, the MDA level was found to be significantly higher in the $E$. coli-infected chickens than in the non-infected birds, suggesting that the presence of the $E$. coli caused oxidative stress in the hosts. The decreased TAC in the infected chickens occurred as a result of consumption of whole body antioxidants due to an increase in the level of oxygen radicals, such as $\mathrm{MDA}^{(23)}$. E. coli secretes various products, including lipopolysaccharide and Haemolysin (HlyA). The latter is a pore-forming toxin. Numerous effects on different cellular populations have been attributed to sublytic concentrations of this toxin, including secretion of ROS and nitric oxide ${ }^{(24)}$. The enhanced generation of ROS may be responsible for the tissue injury due to the septic shock and endotoxaemia induced by $E$. $\operatorname{coli}^{(25)}$. E. coli infection increases the carcinogenicity of nitrosamine precursors and enhances oxidative and nitrosative stresses by increasing the levels of nitric acid, hydrogen peroxide and malondialdehyde ${ }^{(26)}$. In contrast, clindamycin and spectinomycin either alone or in combination ameliorate this adverse effect, as reflected by the significant increases in TAC and significant decreases in MDA compared with the infected, non-treated group. In an experimental model of maternofoetal $E$. coli infection in rabbits, the infection induced an inflammatory response in the foetal lung, causing NO-derived oxidative stress and programmed cell death. Early antibiotic therapy can limit this inflammatory response and decrease the infection-induced oxidative stress and cell death ${ }^{(27)}$. The authors stated that the antibiotics 
achieve these effects by reducing bacterial growth and subsequent inoculum size, and by limiting the inflammatory response, especially cytokine production. Indeed, gentamycin has been shown to inhibit superoxide generation in activated human neutrophils in vitro ${ }^{(28)}$. The present data contrast with the results of Talla and Veerareddy ${ }^{(29)}$ who found that ciprofloxacin and levofloxacin, widely used today for the treatment of bacterial infections, induce more reactive oxygen species in Indian patients. The discrepancy might be attributed to the species studied or the differences in the antibiotics or their doses used.

\section{Conclusion}

From the presented data, it is concluded that oral administration of both clindamycin and / or spectinomycin (therapeutic doses) for 5 successive days therapy has a prime efficacy in the control of the E. coli infection in poultry. Furthermore, paradoxical effects of both clindamycin and spectinomycin combinations showed alterations in some liver and kidney biochemical function parameters as well as oxidative stress. Most of the parameters went back to normal within 2 weeks post drug(s) administration, based on some biochemical measures.

Conflict of Interest statement: The author declares no conflicts of interest.

Table 1. The effect of oral administration of clindamycin and / or spectinomycin (therapeutic and half therapeutic doses) for 5 successive days on serum alanine aminotransferase activity (ALT) of non infected and experimentally infected chickens with $E$. coli. $(\mathbf{n}=5)$

\begin{tabular}{|c|c|c|c|c|c|}
\hline \multirow{3}{*}{ Garameters } & \multicolumn{5}{|c|}{ Serum ALT (U/L) } \\
\hline & \multirow{2}{*}{$\begin{array}{c}\begin{array}{c}\text { During } \\
\text { trea tment }\end{array} \\
4^{\text {th }} \text { day }\end{array}$} & \multicolumn{4}{|c|}{ Post- treatment } \\
\hline & & $2^{\text {nd }}$ day & $7^{\text {th }}$ day & $14^{\text {th }}$ day & $21^{\text {st }}$ day \\
\hline Non-infected, non-treated & $11.04 \pm 0.55 \mathrm{c}$ & $12.70 \pm 0.87 \mathrm{a}$ & $13.90 \pm 0.13 \mathrm{a}$ & $11.50 \pm 0.67 \mathrm{a}$ & $8.60 \pm 0.77 \mathrm{a}$ \\
\hline Non-infected, treated with clindamycin & $14.80 \pm 0.47 \mathrm{~b}$ & $9.80 \pm 0.33 \mathrm{ab}$ & $11.80 \pm 0.54 \mathrm{a}$ & $8.90 \pm 0.85 b$ & $8.80 \pm 0.86 a$ \\
\hline Non-infected, treated with spectinomycin & $15.50 \pm 0.07 \mathrm{~b}$ & $10.30 \pm 0.17 \mathrm{a}$ & $11.70 \pm 0.67 \mathrm{a}$ & $11.60 \pm 0.45 \mathrm{a}$ & $7.20 \pm 0.05 \mathrm{ab}$ \\
\hline $\begin{array}{l}\text { Non-infected, treated with clindamycin and } \\
\text { spectinomycin (half therapeutic doses) combination }\end{array}$ & $11.80 \pm 0.95 \mathrm{c}$ & $11.80 \pm 0.74 \mathrm{a}$ & $10.70 \pm 0.37 \mathrm{ab}$ & $12.30 \pm 0.71 \mathrm{a}$ & $6.20 \pm 0.57 \mathrm{~b}$ \\
\hline $\begin{array}{l}\text { Non-in fected, treated with clindamycin and } \\
\text { spectinomycin (therapeutic doses) }\end{array}$ & $18.90 \pm 0.15 \mathrm{a}$ & $8.60 \pm 0.67 b$ & $12.20 \pm 0.76 \mathrm{a}$ & $9.50 \pm 0.67 \mathrm{ab}$ & $6.80 \pm 0.63 \mathrm{~b}$ \\
\hline Infected, non-treated & $11.23 \pm 0.85 \mathrm{c}$ & $8.16 \pm 0.13 b$ & $11.80 \pm 0.96 \mathrm{a}$ & $8.80 \pm 0.72 b$ & $7.10 \pm 0.81 \mathrm{ab}$ \\
\hline Infected, treated with clindamycin & $13.74 \pm 0.16 \mathrm{bc}$ & $8.20 \pm 0.91 \mathrm{~b}$ & $11.20 \pm 0.17 \mathrm{a}$ & $9.80 \pm 0.34 \mathrm{ab}$ & $7.30 \pm 0.67 \mathrm{ab}$ \\
\hline Infected, treated with spectinomycin & $12.88 \pm 0.24 c$ & $8.70 \pm 0.96 \mathrm{~b}$ & $9.60 \pm 0.89 \mathrm{~b}$ & $10.90 \pm 0.19 \mathrm{ab}$ & $8.10 \pm 0.49 \mathrm{a}$ \\
\hline $\begin{array}{l}\text { Infected, treated with clindamycin and } \\
\text { spectinomycin (half therapeutic doses) combination }\end{array}$ & $11.15 \pm 0.81 \mathrm{c}$ & $8.33 \pm 0.66 \mathrm{~b}$ & $8.90 \pm 0.78 b$ & $9.70 \pm 0.82 \mathrm{~b}$ & $9.70 \pm 1.09 \mathrm{a}$ \\
\hline $\begin{array}{l}\text { In fected, treated with clindamycin and } \\
\text { spectinomycin (therapeutic doses) }\end{array}$ & $12.67 \pm 0.19 \mathrm{c}$ & $7.87 \pm 0.77 \mathrm{~b}$ & $8.80 \pm 0.83 \mathrm{~b}$ & $11.50 \pm 0.22 \mathrm{a}$ & $8.10 \pm 0.91 \mathrm{a}$ \\
\hline
\end{tabular}

The means with different superscripts in the same column indicate significantly different, $(\mathrm{p}<0.05)$.

* Compared with control group (non infected, non treated).

+ Compared with infected control group (infected, non treated) 
Table 2. The effect of oral administration of clindamycin and / or spectinomycin (therapeutic and half therapeutic doses) for 5 successive days on serum alkaline phosphatase activity (ALP) of non infected and experimentally infected chickens with $E$. coli. $(\mathbf{n}=5)$

\begin{tabular}{|c|c|c|c|c|c|}
\hline \multirow{3}{*}{ Groups } & \multicolumn{5}{|c|}{ Serum ALP (U/L) } \\
\hline & \multirow{3}{*}{$\begin{array}{c}\begin{array}{c}\text { During } \\
\text { treatment }\end{array} \\
4^{\text {th }} \text { day } \\
17.73 \pm 0.15 \mathrm{c}\end{array}$} & \multicolumn{4}{|c|}{ Post- treatment } \\
\hline & & $2^{\text {sd }}$ day & $7^{\text {th }}$ day & $14^{\text {th }}$ day & $21^{\text {st }} \mathrm{day}$ \\
\hline Non-infected, non-treated & & $16.20 \pm 0.27 b$ & $16.50 \pm 0.93 \mathrm{~b}$ & $13.70 \pm 0.87 \mathrm{~b}$ & $17.60 \pm 0.66 \mathrm{a}$ \\
\hline Non-infected, treated with clindamycin & $20.60 \pm 0.97 \mathrm{~b}$ & $16.40 \pm 0.63 \mathrm{~b}$ & $15.80 \pm 0.77 \mathrm{~cd}$ & $14.10 \pm 0.09 \mathrm{~b}$ & $13.80 \pm 0.61 \mathrm{~b}$ \\
\hline Non-infected, treated with spectinomycin & $17.09 \pm 0.76 \mathrm{c}$ & $16.70 \pm 0.23 \mathrm{~b}$ & $15.70 \pm 0.31 \mathrm{~cd}$ & $13.90 \pm 0.24 \mathrm{~b}$ & $13.30 \pm 0.59 \mathrm{~b}$ \\
\hline $\begin{array}{l}\text { Non-infected, treated with clindamycin and } \\
\text { spectinomycin (half therapeutic doses) combination }\end{array}$ & $15.40 \pm 0.31 \mathrm{c}$ & $14.30 \pm 0.58 \mathrm{c}$ & $14.20 \pm 0.69 \mathrm{c}$ & $16.80 \pm 0.69 \mathrm{a}$ & $17.80 \pm 0.61 \mathrm{a}$ \\
\hline $\begin{array}{l}\text { Non-infected, trea ted with clindamycin and } \\
\text { spectinomycin (therapeutic doses) }\end{array}$ & $16.30 \pm 0.47 \mathrm{c}$ & $15.40 \pm 0.00 \mathrm{~cd}$ & $14.70 \pm 0.32 \mathrm{c}$ & $16.50 \pm 0.30 \mathrm{a}$ & $15.50 \pm 0.31 \mathrm{~b}$ \\
\hline Infected, non-treated & $17.83 \pm 0.33 \mathrm{c}$ & $21.26 \pm 0.57 \mathrm{a}$ & $24.10 \pm 0.16 \mathrm{a}$ & $13.40 \pm 0.88 \mathrm{~b}$ & $13.70 \pm 0.25 \mathrm{~b}$ \\
\hline Infected, treated with clindamycin & $28.57 \pm 0.47 \mathrm{a}$ & $24.15 \pm 0.11 \mathrm{a}$ & $26.40 \pm 0.54 \mathrm{a}$ & $12.70 \pm 0.75 \mathrm{~b}$ & $17.10 \pm 0.07 \mathrm{a}$ \\
\hline Infected, treated with spectinomycin & $19.68 \pm 0.38 b$ & $18.60 \pm 0.36 \mathrm{~b}$ & $14.30 \pm 0.28 \mathrm{c}$ & $14.10 \pm 0.59 \mathrm{~b}$ & $12.90 \pm 0.06 \mathrm{~b}$ \\
\hline $\begin{array}{l}\text { Infected, treated with clindamycin and } \\
\text { spectinomycin (half therapeutic doses) combination }\end{array}$ & $13.15 \pm 0.01 \mathrm{~d}$ & $16.83 \pm 0.72 \mathrm{~b}$ & $13.90 \pm 0.62 c$ & $16.30 \pm 0.14 \mathrm{a}$ & $15.60 \pm 0.46 \mathrm{~b}$ \\
\hline $\begin{array}{c}\text { Infected, treated with clindamycin and spectinomycin } \\
\text { (therapeutic doses) }\end{array}$ & $15.27 \pm 0.89 \mathrm{c}$ & $15.97 \pm 0.61 \mathrm{~cd}$ & $19.60 \pm 0.36 \mathrm{~b}$ & $16.50 \pm 0.92 \mathrm{a}$ & $13.80 \pm 0.28 \mathrm{~b}$ \\
\hline
\end{tabular}

The means with different superscripts in the same column indicate significantly different, $(\mathrm{p}<0.05)$.

* Compared with control group (non infected, non treated)

+ Compared with infected control group (infected, non treated).

Table 3. The effect of oral administration of clindamycin and / or spectinomycin (therapeutic and half therapeutic doses) for 5 successive days on serum total protein of non infected and experimentally infected chickens with $E$. coli. $(\mathbf{n}=5)$

\begin{tabular}{|c|c|c|c|c|c|}
\hline Parameters & \multicolumn{5}{|c|}{ Serum total protein (g/dl) } \\
\hline \multirow{2}{*}{ Groups } & $\begin{array}{c}\text { During } \\
\text { treatment }\end{array}$ & \multicolumn{4}{|c|}{ Post- treatment } \\
\hline & \multirow{2}{*}{$\begin{array}{l}4^{\text {th }} \text { day } \\
6.57 \pm 0.19 \mathrm{a}\end{array}$} & \multirow{2}{*}{$\begin{array}{l}2^{\text {nd }} \text { day } \\
5.30 \pm 0.08 a\end{array}$} & \multirow{2}{*}{$\begin{array}{l}7^{\text {th }} \text { day } \\
6.09 \pm 0.13 \mathrm{a}\end{array}$} & \multirow{2}{*}{$\begin{array}{l}14^{\text {th }} \text { day } \\
5.30 \pm 0.07 \mathrm{a}\end{array}$} & \multirow{2}{*}{$\begin{array}{l}21^{\text {st }} \text { day } \\
5.20 \pm 0.06 \mathrm{a}\end{array}$} \\
\hline Non-infected, non-treated & & & & & \\
\hline Non-infected, treated with clindamycin & $5.87 \pm 0.16 \mathrm{~b}$ & $4.90 \pm 0.13 \mathrm{ab}$ & $5.60 \pm 0.17 \mathrm{~b}$ & $4.60 \pm 0.09 \mathrm{ab}$ & $4.80 \pm 0.11 \mathrm{ab}$ \\
\hline Non-infected, treated with spectinomycin & $5.85 \pm 0.11 \mathrm{~b}$ & $4.97 \pm 0.12 \mathrm{ab}$ & $5.87 \pm 0.11 \mathrm{ab}$ & $4.40 \pm 0.14 \mathrm{~b}$ & $4.70 \pm 0.17 \mathrm{~b}$ \\
\hline $\begin{array}{l}\text { Non-infected, treated with clindamycin and } \\
\text { spectinomycin (half therapeutic doses) } \\
\text { combination }\end{array}$ & $5.82 \pm 0.16 \mathrm{~b}$ & $4.67 \pm 0.18 \mathrm{~b}$ & $5.85 \pm 0.19 \mathrm{ab}$ & $4.30 \pm 0.11 \mathrm{~b}$ & $4.80 \pm 0.11 \mathrm{ab}$ \\
\hline $\begin{array}{l}\text { Non-in fected, treated with clindamycin and } \\
\text { spectinomycin (therapeutic doses) }\end{array}$ & $6.41 \pm 0.11 \mathrm{a}$ & $4.61 \pm 0.10 \mathrm{~b}$ & $5.70 \pm 0.12 \mathrm{~b}$ & $4.30 \pm 0.10 \mathrm{~b}$ & $5.00 \pm 0.18 \mathrm{a}$ \\
\hline Infected, non-treated & $5.97 \pm 0.15 b$ & $4.76 \pm 0.17 \mathrm{~b}$ & $5.50 \pm 0.16 \mathrm{~b}$ & $4.10 \pm 0.11 \mathrm{~b}$ & $4.70 \pm 0.04 \mathrm{~b}$ \\
\hline Infected, treated with clindamycin & $6.07 \pm 0.12 \mathrm{ab}$ & $4.85 \pm 0.11 \mathrm{ab}$ & $5.40 \pm 0.14 b$ & $5.10 \pm 0.15 \mathrm{a}$ & $5.50 \pm 0.07 \mathrm{a}$ \\
\hline Infected, treated with spectinomycin & $5.86 \pm 0.15 b$ & $5.00 \pm 0.10 \mathrm{a}$ & $5.50 \pm 0.18 \mathrm{~b}$ & $5.10 \pm 0.17 \mathrm{a}$ & $5.60 \pm 0.16 \mathrm{a}$ \\
\hline $\begin{array}{l}\text { Infected, treated with clindamycin and } \\
\text { spectinomycin (half therapeutic doses) } \\
\text { combination }\end{array}$ & $6.19 \pm 0.11 \mathrm{ab}$ & $4.93 \pm 0.12 \mathrm{ab}$ & $5.60 \pm 0.12 \mathrm{~b}$ & $4.80 \pm 0.04 \mathrm{ab}$ & $4.80 \pm 0.16 \mathrm{~b}$ \\
\hline $\begin{array}{l}\text { In fected, treated with clindamycin and } \\
\text { spectinomycin (therapeutic doses) }\end{array}$ & $6.55 \pm 0.19 \mathrm{a}$ & $4.37 \pm 0.11 \mathrm{~b}$ & $6.20 \pm 0.13 \mathrm{a}$ & $4.20 \pm 0.16 \mathrm{~b}$ & $5.30 \pm 0.11 \mathrm{a}$ \\
\hline
\end{tabular}

The means with different superscripts in the same column indicate significantly different, $(\mathrm{p}<0.05)$.

* Compared with control group (non infected, non treated).

+ Compared with infected control group (infected, non treated). 
Table 4. The effect of oral administration of clindamycin and /or spectinomycin (therapeutic and half therapeutic doses) for 5 successive days on serum creatinine of non infected and experimentally infected chickens with $E$. coli. $(\mathbf{n}=5)$

\begin{tabular}{|c|c|c|c|c|c|}
\hline Parameters & & Serum & creatinine (n & /dl) & \\
\hline & $\begin{array}{l}\text { During } \\
\text { treatment }\end{array}$ & & Post- tr & atment & \\
\hline Groups & $4^{\text {th }}$ day & $2^{\text {nd }}$ day & $7^{\text {th }}$ day & $14^{\text {th }}$ day & $21^{\text {st }}$ day \\
\hline Non-infected, non-treated & $0.68 \pm 0.01 \mathrm{c}$ & $0.45 \pm 0.01 d$ & $0.64 \pm 0.01 \mathrm{a}$ & $0.60 \pm 0.01 b c$ & $0.65 \pm 0.01 \mathrm{a}$ \\
\hline Non-infected, treated with clindamycin & $0.64 \pm 0.01 d$ & $0.48 \pm 0.006 \mathrm{~d}$ & $0.59 \pm 0.01 \mathrm{ab}$ & $0.58 \pm 0.02 \mathrm{bc}$ & $0.55 \pm 0.01 b$ \\
\hline Non-infected, treated with spectinomycin & $0.65 \pm 0.01 \mathrm{~cd}$ & $0.51 \pm 0.02 \mathrm{c}$ & $0.56 \pm 0.01 \mathrm{~b}$ & $0.65 \pm 0.01 \mathrm{~b}$ & $0.56 \pm 0.01 \mathrm{~b}$ \\
\hline $\begin{array}{c}\text { Non-infected, treated with clindamycin and } \\
\text { spectinomycin (half therapeutic doses) } \\
\text { combination }\end{array}$ & $0.68 \pm 0.01 \mathrm{c}$ & $0.51 \pm 0.01 \mathrm{c}$ & $0.59 \pm 0.01 \mathrm{ab}$ & $0.78 \pm 0.01 \mathrm{a}$ & $0.55 \pm 0.002 \mathrm{~b}$ \\
\hline $\begin{array}{l}\text { Non-infected, treated with clindamycin and } \\
\text { spectinomycin (therapeutic doses) }\end{array}$ & $0.66 \pm 0.01 \mathrm{~cd}$ & $0.51 \pm 0.004 \mathrm{c}$ & $0.60 \pm 0.02 \mathrm{ab}$ & $0.52 \pm 0.005 \mathrm{c}$ & $0.55 \pm 0.01 \mathrm{~b}$ \\
\hline Infected, non-treated & $0.67 \pm 0.03 c$ & $0.52 \pm 0.01 \mathrm{c}$ & $0.58 \pm 0.01 \mathrm{~b}$ & $0.66 \pm 0.01 b$ & $0.51 \pm 0.01 \mathrm{c}$ \\
\hline Infected, treated with clindamycin & $0.84 \pm 0.01 \mathrm{a}$ & $0.67 \pm 0.01 \mathrm{a}$ & $0.65 \pm 0.01 \mathrm{a}$ & $0.59 \pm 0.01 b c$ & $0.53 \pm 0.02 \mathrm{c}$ \\
\hline Infected, treated with spectinomycin & $0.63 \pm 0.01 \mathrm{~d}$ & $0.55 \pm 0.02 \mathrm{~b}$ & $0.56 \pm 0.03 \mathrm{~b}$ & $0.71 \pm 0.01 \mathrm{a}$ & $0.55 \pm 0.006 \mathrm{~b}$ \\
\hline $\begin{array}{l}\text { Infected, treated with clindamycin and } \\
\text { spectinomycin (half therapeutic doses) } \\
\text { combination }\end{array}$ & $0.75 \pm 0.01 b$ & $0.49 \pm 0.003 \mathrm{~d}$ & $0.52 \pm 0.02 \mathrm{~b}$ & $0.58 \pm 0.02 \mathrm{bc}$ & $0.52 \pm 0.008 \mathrm{c}$ \\
\hline $\begin{array}{l}\text { Infected, treated with clindamycin and } \\
\text { spectinomycin (therapeutic doses) }\end{array}$ & $0.79 \pm 0.02 b$ & $0.56 \pm 0.01 \mathrm{~b}$ & $0.57 \pm 0.01 \mathrm{~b}$ & $0.52 \pm 0.01 \mathrm{c}$ & $0.57 \pm 0.004 \mathrm{~b}$ \\
\hline
\end{tabular}

The means with different superscripts in the same column indicate significantly different, $(\mathrm{p}<0.05)$.

* Compared with control group (non infected, non treated).

+ Compared with infected control group (infected, non treated)

Table 5. The effect of oral administration of clindamycin and / or spectinomycin (therapeutic and half therapeutic doses) for 5 successive days on serum uric acid of non infected and experimentally infected chickens with $E$. coli. $(\mathbf{n}=5)$

\begin{tabular}{|c|c|c|c|c|c|}
\hline \multirow{3}{*}{ Groups } & \multicolumn{5}{|c|}{ Serum uric acid (mg/dl) } \\
\hline & $\begin{array}{c}\text { During } \\
\text { treatment }\end{array}$ & \multicolumn{4}{|c|}{ Post- treatment } \\
\hline & \multirow{2}{*}{$\begin{array}{c}4^{\text {th }} \text { day } \\
10.38 \pm 0.01 a b\end{array}$} & \multirow{2}{*}{$\begin{array}{l}\mathbf{2}^{\text {nd }} \text { day } \\
9.15 \pm 0.01 b\end{array}$} & \multirow{2}{*}{$\begin{array}{l}7^{\text {th }} \text { day } \\
8.54 \pm 0.01 b\end{array}$} & \multirow{2}{*}{$\begin{array}{l}14^{\text {th }} \text { day } \\
8.66 \pm 0.01 \mathrm{a}\end{array}$} & \multirow{2}{*}{$\begin{array}{l}21^{\text {st }} \text { day } \\
5.65 \pm 0.01 b\end{array}$} \\
\hline Non-infected, non-treated & & & & & \\
\hline Non-infected, treated with clindamycin & b. $24 \pm 0.01 b$ & $7.38 \pm 0.01 \mathrm{c}$ & $7.49 \pm 0.01 \mathrm{c}$ & $7.78 \pm 0.02 \mathrm{~b}$ & $4.55 \pm 0.01 \mathrm{~b}$ \\
\hline Non-infected, treated with spectinomycin & $11.85 \pm 0.01 \mathrm{a}$ & $10.61 \pm 0.03 \mathrm{a}$ & $8.56 \pm 0.01 b$ & $6.55 \pm 0.01 \mathrm{~b}$ & $4.56 \pm 0.01 b$ \\
\hline $\begin{array}{c}\text { Non-infected, treated with clindamycin and } \\
\text { spectinomycin (half therapeutic doses) } \\
\text { combination }\end{array}$ & $9.68 \pm 0.01 \mathrm{~b}$ & $9.71 \pm 0.01 \mathrm{~b}$ & $9.49 \pm 0.01 \mathrm{a}$ & $7.88 \pm 0.01 \mathrm{~b}$ & $6.55 \pm 0.01 \mathrm{a}$ \\
\hline $\begin{array}{l}\text { Non-infected, treated with clindamycin and } \\
\text { spectinomycin (therapeutic doses) }\end{array}$ & $8.86 \pm 0.01 b$ & $8.61 \pm 0.01 b$ & $8.65 \pm 0.01 b$ & $5.62 \pm 0.01 \mathrm{c}$ & $5.55 \pm 0.01 \mathrm{~b}$ \\
\hline Infected, non-treated & $9.67 \pm 0.01 \mathrm{~b}$ & $9.82 \pm 0.01 \mathrm{~b}$ & $9.55 \pm 0.01 \mathrm{a}$ & $6.46 \pm 0.01 \mathrm{~b}$ & $6.51 \pm 0.01 \mathrm{a}$ \\
\hline Infected, treated with clindamycin & $11.84 \pm 0.01 \mathrm{a}$ & $9.47 \pm 0.02 \mathrm{~b}$ & $8.75 \pm 0.01 b$ & $9.69 \pm 0.01 \mathrm{a}$ & $7.53 \pm 0.02 \mathrm{a}$ \\
\hline Infected, treated with spectinomycin & $9.83 \pm 0.01 \mathrm{~b}$ & $9.85 \pm 0.01 b$ & $8.46 \pm 0.01 b$ & $9.61 \pm 0.01 \mathrm{a}$ & $6.55 \pm 0.01 \mathrm{a}$ \\
\hline $\begin{array}{l}\text { Infected, treated with clindamycin and } \\
\text { spectinomycin (half therapeutic doses) } \\
\text { combination }\end{array}$ & $11.45 \pm 0.01 \mathrm{a}$ & $10.19 \pm 0.01 \mathrm{a}$ & $8.72 \pm 0.02 \mathrm{~b}$ & $9.68 \pm 0.01 \mathrm{a}$ & $6.52 \pm 0.01 \mathrm{a}$ \\
\hline $\begin{array}{l}\text { In fected, treated with clindamycin and } \\
\text { spectinomycin (therapeutic doses) }\end{array}$ & $12.89 \pm 0.01 \mathrm{a}$ & $11.66 \pm 0.01 \mathrm{a}$ & $9.67 \pm 0.01 \mathrm{a}$ & $8.57 \pm 0.01 \mathrm{a}$ & $7.57 \pm 0.01 \mathrm{a}$ \\
\hline
\end{tabular}

The means with different superscripts in the same column indicate significantly different, $(\mathrm{p}<0.05)$.

* Compared with control group (non infected, non treated).

+ Compared with infected control group (infected, non treated). 
Table 6. The effect of oral administration of clindamycin and / or spectinomycin (therapeutic and half therapeutic doses) for 5 successive days on serum (TAC) of non infected and experimentally infected chickens with $E$. coli. (n=5)

\begin{tabular}{|c|c|c|c|c|c|}
\hline \multirow[t]{3}{*}{ Parameters } & \multicolumn{5}{|c|}{ Serum T AC ( $\mathrm{mM} / \mathrm{L})$} \\
\hline & \multirow{2}{*}{$\begin{array}{c}\begin{array}{c}\text { During } \\
\text { treatment }\end{array} \\
4^{\text {th }} \text { day }\end{array}$} & \multicolumn{4}{|c|}{ Post- treatment } \\
\hline & & $2^{\text {nd }}$ day & $7^{\text {th }}$ day & $14^{\text {th }}$ day & $21^{\text {st }}$ day \\
\hline Non-infected, non-treated & $0.545 \pm 0.003 \mathrm{~b}$ & $0.567 \pm 0.01 \mathrm{~b}$ & $1.540 \pm 0.008 \mathrm{ab}$ & $0.779 \pm 0.006 \mathrm{~b}$ & $0.539 \pm 0.004 \mathrm{~b}$ \\
\hline Non-infected, treated with clindamycin & $0.636 \pm 0.007 \mathrm{ab}$ & $0.589 \pm 0.10 \mathrm{~b}$ & $1.573 \pm 0.001 \mathrm{ab}$ & $0.813 \pm 0.004 \mathrm{ab}$ & $0.547 \pm 0.003 b$ \\
\hline Non-infected, treated with spectinomycin & $0.743 \pm 0.001 \mathrm{a}$ & $0.766 \pm 0.12 \mathrm{a}$ & $1.811 \pm 0.004 \mathrm{a}$ & $1.060 \pm 0.009 \mathrm{a}$ & $0.789 \pm 0.007 \mathrm{a}$ \\
\hline $\begin{array}{c}\text { Non-infected, treated with clindamycin and } \\
\text { spectinomycin (half therapeutic doses) } \\
\text { combination }\end{array}$ & $0.676 \pm 0.001 \mathrm{ab}$ & $0.787 \pm 0.14 \mathrm{a}$ & $1.845 \pm 0.001 \mathrm{a}$ & $0.991 \pm 0.002 \mathrm{a}$ & $0.764 \pm 0.005 \mathrm{a}$ \\
\hline $\begin{array}{l}\text { Non-infected, treated with clindamycin and } \\
\text { spectinomycin (therapeutic doses) }\end{array}$ & $0.824 \pm 0.007 \mathrm{a}$ & $0.833 \pm 0.16 \mathrm{a}$ & $1.876 \pm 0.009 \mathrm{a}$ & $1.084 \pm 0.005 \mathrm{a}$ & $0.878 \pm 0.003 \mathrm{a}$ \\
\hline Infected, non-treated & $0.314 \pm 0.008 \mathrm{c}$ & $0.281 \pm 0.003 \mathrm{c}$ & $0.767 \pm 0.002 \mathrm{~b}$ & $0.471 \pm 0.007 \mathrm{c}$ & $0.380 \pm 0.005 \mathrm{c}$ \\
\hline Infected, treated with clindamycin & $0.360 \pm 0.002 c$ & $0.369 \pm 0.005 \mathrm{c}$ & $0.798 \pm 0.006 \mathrm{~b}$ & $0.665 \pm 0.008 \mathrm{~b}$ & $0.471 \pm 0.007 \mathrm{~b}$ \\
\hline Infected, treated with spectinomycin & $0.477 \pm 0.003 \mathrm{~b}$ & $0.518 \pm 0.008 \mathrm{~b}$ & $0.901 \pm 0.007 \mathrm{~b}$ & $0.878 \pm 0.003 \mathrm{ab}$ & $0.760 \pm 0.008 \mathrm{a}$ \\
\hline $\begin{array}{l}\text { Infected, treated with clindamycin and } \\
\text { spectinomycin (half therapeutic doses) } \\
\text { combination }\end{array}$ & $0.486 \pm 0.006 \mathrm{~b}$ & $0.531 \pm 0.003 b$ & $1.198 \pm 0.003 b$ & $0.802 \pm 0.006 \mathrm{ab}$ & $0.687 \pm 0.006 \mathrm{ab}$ \\
\hline $\begin{array}{l}\text { Infected, treated with clindamycin and } \\
\text { spectinomycin (therapeutic doses) }\end{array}$ & $0.525 \pm 0.004 \mathrm{~b}$ & $0.543 \pm 0.006 \mathrm{~b}$ & $0.987 \pm 0.008 b$ & $0.868 \pm 0.009 \mathrm{ab}$ & $0.794 \pm 0.004 a$ \\
\hline
\end{tabular}

The means with different superscripts in the same column indicate significantly different, $(\mathrm{p}<0.05)$.

* Compared with control group (non infected, non treated).

+ Compared with infected control group (infected, non treated)

Table 7. The effect of oral administration of clindamycin and / or spectinomycin (therapeutic and half therapeutic doses) for 5 successive days on serum (MDA) of non infected and experimentally infected chickens with $E$. coli. (n=5)

\begin{tabular}{|c|c|c|c|c|c|}
\hline \multirow{3}{*}{ Parameters } & \multicolumn{5}{|c|}{ Serum MDA (nmol $/ \mathrm{ml})$} \\
\hline & \multirow{3}{*}{$\begin{array}{c}\begin{array}{c}\text { During } \\
\text { treatment }\end{array} \\
4^{\text {th }} \text { day } \\
32.16 \pm 2.77 \mathrm{c}\end{array}$} & \multicolumn{4}{|c|}{ Post- treatment } \\
\hline & & $2^{\text {nd }}$ day & $7^{\text {th }}$ day & $14^{\text {th }}$ day & $21^{\text {st }}$ day \\
\hline \multirow{3}{*}{$\begin{array}{l}\text { Non-infected, non-treated } \\
\text { Non-infected, treated with clindamycin } \\
\text { Non-infected, treated with spectinomycin }\end{array}$} & & $37.22 \pm 3.30 \mathrm{bc}$ & $42.56 \pm 2.17 \mathrm{c}$ & $46.27 \pm 3.15 \mathrm{c}$ & $39.83 \pm 4.03 \mathrm{c}$ \\
\hline & $30.78 \pm 3.68 \mathrm{c}$ & $33.15 \pm 4.08 b c$ & $43.32 \pm 3.30 c$ & $41.18=4.90 c$ & $40.02 \pm 5.87 \mathrm{c}$ \\
\hline & $26.11 \pm 2.32 \mathrm{~d}$ & $25.58 \pm 3.41 \mathrm{c}$ & $40.69 \pm 2.16 c$ & $44.83 \pm 4.21 \mathrm{c}$ & $39.42 \pm 2.62 c$ \\
\hline $\begin{array}{c}\text { Non-infected, treated with clindamycin and } \\
\text { spectinomycin (half therapeutic doses) } \\
\text { combination }\end{array}$ & $29.71 \pm 3.81 \mathrm{c}$ & $28.19 \pm 2.13 c$ & $43.58 \pm 4.39 c$ & $41.92 \pm 3.38 \mathrm{c}$ & $38.17 \pm 3.18 \mathrm{c}$ \\
\hline $\begin{array}{l}\text { Non-infected, treated with clindamycin and } \\
\text { spectinomycin (therapeutic doses) combination }\end{array}$ & $24.65 \pm 2.93 \mathrm{~d}$ & $25.62 \pm 3.72 \mathrm{c}$ & $40.06 \pm 4.84 c$ & $42.28 \pm 5.24 c$ & $40.34 \pm 2.29 c$ \\
\hline Infected, non-treated & $53.16 \pm 5.87 \mathrm{a}$ & $59.74 \pm 6.43 \mathrm{a}$ & $71.08 \pm 5.17 \mathrm{a}$ & $76.62 \pm 3.67 \mathrm{a}$ & $64.92 \pm 4.16 \mathrm{a}$ \\
\hline Infected, treated with clindamycin & $48.80 \pm 4.95 \mathrm{a}$ & $52.91 \pm 6.18 \mathrm{a}$ & $68.78 \pm 4.72 \mathrm{a}$ & $72.31 \pm 5.49 \mathrm{a}$ & $63.57 \pm 3.46 \mathrm{a}$ \\
\hline Infected, treated with spectinomycin & $46.31 \pm 3.55 b$ & $47.29 \pm 4.31 b$ & $55.27 \pm 3.29 b$ & $66.17 \pm 5.71 b$ & $52.03 \pm 3.93 b$ \\
\hline $\begin{array}{l}\text { Infected, treated with clindamycin and } \\
\text { spectinomycin (half therapeutic doses) } \\
\text { combination }\end{array}$ & $41.57 \pm 2.79 b$ & $51.18 \pm 3.58 \mathrm{a}$ & $56.02 \pm 4.13 \mathrm{~b}$ & $68.09 \pm 2.83 b$ & $57.43 \pm 4.62 \mathrm{~b}$ \\
\hline $\begin{array}{l}\text { Infected, treated with clindamycin and } \\
\text { spectinomycin (therapeutic doses) combination }\end{array}$ & $42.17 \pm 3.63 b$ & $48.30 \pm 4.19 b$ & $52.13 \pm 3.82 \mathrm{~b}$ & $68.79 \pm 4.71 b$ & $50.28 \pm 2.41 b$ \\
\hline
\end{tabular}

The means with different superscripts in the same column indicate significantly different, $(\mathrm{p}<0.05)$.

* Compared with control group (non infected, non treated).

+ Compared with infected control group (infected, non treated).

\section{References}

1. Huff WE, Huff GR, Rath NC, Balog J M and Donoghue A M. Prevention of Escherichia coli Infection in Broiler Chickens with a Bacteriophage Aerosol Spray. Poultry Sci. 2002, 81, 1486-1491.

2. Dziva $\mathrm{F}$ and Stevens MP. Colibacillosis in poultry: unravelling the molecular basis of virulence of avian pathogenic Escherichia coli in their natural hosts. Avian Pathol. 2008, 37(4), 355-66.

3. American Veterinary Medical Association. 2013. American Association of Avian Pathologists Guidelines to Judicious Therapeutic Use of Antimicrobials in Poultry. https://www.avma.org/ (accessed 4 January 2014).
4. Harry W, Lampiris MD and Aniel SM. 1998. Clinical use of antimicrobial agents In, Basic and Clinical Pharmacol. 7th edn., Katzung, B. G. (ed) Stanford, Appleton and Lange, New York, pp. $812-826$.

5. Agunos A, Léger D and Carson C. Review of antimicrobial therapy of selected bacterial diseases in broiler chickens in Canada. Can. Vet. J. 2012, 53, 12891300.

6. Barragry TB. 1994. Veterinary drug therapy. Baltimore: Lea \& Febiger, pp. 251-62.

7. Cuerpo L and Livingston RC. Spectinomycin. In: Residues of some veterinary drugs in animals and foods. 
Monographs prepared by the forty-second meeting of the joint FAO/WHO expert committee on food additives. FAO Food Nutr. 1994, 41(6), 1- 86.

8. Prescott JF. 2000. Lincosamides, Macrolides, and Pleuromutilins. In: Antimicrobial therapy in veterinary medicine.Eds., J.F. Prescott, J.D. Baggot and R.D. Walker Third Edition, Iowa State University Press, Ames, Iowa, USA, pp. 229-262.

9. Chansiripornchai $\mathrm{N}$ and Sasipreeyajan J. Efficacy of sarafloxacin in broilers after experimental infection with Escherichia coli. Vet. Res. Commun., 2002; 26: 255-62.

10. National Committee for Clinical Laboratory Standards (NCCLS), Performance Standards for Antimicrobial Susceptibility Testing, Twelfth Informational Supplement. NCCLS document. 2003, NCCLS 940 West Valley Road, Suite 1400, Wayne, PA 19087-1898 USA.

11. Humble M, Eykyn W and Phillips I. Staphylococcal bacteraemia, fusidic acid, and jaundice. Br. Med. J. 1980; 280: 1495-1498.

12. Ramachandran R and Kakar S. Histological patterns in drug-induced liver disease. J. Clin. Pathol. 2009; 62:481492.

13. Smith CM and Reynard AM. 1992. Textbook of Pharmacology. Philadelphia, W.B. Saunders Company.

14. Plumb DC. Veterinary drug Handbook. $2^{\text {nd }}$ Ed. Ames, Iowa State University press. Smith, C.M. and Reynard, A.M. Textbook of Pharmacology, 1 Ed. Saunders, pp. 324328.

15. Gilman AG. 2001. Pharmacological basis of therapeutics. $10^{\text {th }}$ Edition; McGraw-Hill Medical, USA. pp. 134-142.

16. Zaki MS, Fawzy O and Osfor H. Effect of E. coli OH157 on Baladi Broiler Chicken and some Biochemical studies. Life Sci. J. 2002, 9(1), 91-94.

17. Elmore M, Rissing JP Rink L and Brooks GF. Clindamycin-associated hepatotoxicity. Am. J. Med. 1974; 57(4):627-30.

18. Ali S M. 2007. Concurrent use of clindamycin with spectinomycin (Clindaspectin) in broiler chicks. Thesis for the degree of M.V.Sc. (Pharmacology). Fac. Vet. Med. Zagazig. Univ.

19. Mohamed FAE.1995. Evaluation of possible concurrent use of both lincomycin and spectinomycin in chickens. Thesis for the degree of M.V.Sc. (Pharmacology). Fac. Vet. Med. Zagazig. Univ.

20. El-Kadeem A EM. 2005. Pharmacological studies of gentamycin and ciprofloxacin in collibacillosis in chickens. Thesis for the degree of M.V.Sc. (Pharmacology). Fac. Vet. Med. Zagazig. Univ.

21. Van den Broek, A.H.M. Serum protein values in canine diabetes mellitus, hypothyroidism and hypoadrenocorticism, British Vet. J.1992, 148, 259-263.

22. Elmo DS, Frck, HD and Charles JD. Alteration the blood chemistry of chick treated with endotoxin of salmonella pullorum. J. Bact. 1958, 75, 719-723.

23. Karaman U, Kiran TR, Colak C, Iraz M, Celik Tand Karabulut AB. Serum Malondialdehyde, glutathione and nitric oxide levels in patients infected with Entamoeba coli. Int. J. Med. Sci. 2009, 1(5), 235-237.

24. Suttorp N, Fuhrmann M, Tannert-Otto S, Grimminger F and Bhadki S. Pore-forming bacterial toxins potently induce release of nitric oxide in porcine endothelial cells. J. Exp. Med. 1993, 178(1), 337-341.

25. Kaymak C, Kadioglu E, Ozcagli E, Osmanoglu G, Izdes $\mathrm{S}$, Agalar C, Basar $\mathrm{H}$ and Sardas S. Oxidative DNA damage and total antioxidant status in rats during experimental gram-negative sepsis. Hum. Exp. Toxicol. 2008, 27(6), 485-91.

26. Ashmawey AM, Mohamed WS, Abdel-Salam IM, ElGendy M, Ali AI and El-Aaser A. Role of Urinary Tract Bacterial Infection in the Process of Bladder Carcinogenesis (Molecular and Biochemical Studies). Asian J. Med. Sci. 2011, 2, 31-40.

27. Gras-Le Guen C, Jarry A, Vallette G, Toquet C, Colombeix C, Laboisse CL, Potel G, Roze JC, Bugnon D and Debillon T. Antibiotic therapy reduces nitrosative stress and programmed cell death in the rabbit. Eur. Respir. J. 2005, 25, 88-95.

28. Umeki S. Inflammatory action of gentamycin through inhibitory effect on neutrophil NADPH oxidase activity. Comp. Biochem. Physiol. Biochem. Mol. Biol. 1995, 110, $817-821$.

29. Talla V and Veerareddy PR. Oxidative Stress Induced by Fluoroquinolones on Treatment for Complicated Urinary Tract Infections in Indian Patients. J. Young. Pharm. 2011, 3(4), 304-309. 